\title{
THE USE OF NESTED-PCR TO DETECT THE PRESENCE OF PLASMODIUM IN ANOPHELES ARABIENSIS IN JAZAN REGION, SAUDI ARABIA \\ By
}

A.A. ALSHEIKH ${ }^{1}$, A.A. ALBARRAK ${ }^{2}$, O.M. DAFFALLA ${ }^{1}$, E.M. NOURELDIN ${ }^{1}$, W.S. MOHAMMED ${ }^{1}$, K.J. SHRWANI ${ }^{1}$, Y.A.HOBANI ${ }^{1}$, M.M. ZAMIM ${ }^{1}$ AND A.M. ASSIRI ${ }^{3}$

National Center for Vector-Borne Diseases, MoH-Jazan ${ }^{1}$, Minister Deputy for Public Health, MoH-Riyadh², Saudi Arabia and General Director of Saudi CDC ${ }^{3}$.

( ${ }^{\star}$ Correspondence: adelalsheikh@gmail.com)

\begin{abstract}
The present study was carried out in 26 villages at two Governates (Al-Khobah, and Haroob) in Jazan Region in Southwest Saudi Arabia to identify and detect the presence of Plasmodium in Anopheles arabiensis using nested-PCR technique.

An. Arabiensis was identified by PCR and it was the predominant Anopheles mosquito in all the collection sites. A total of 257 An. Arabiensis females were collected and two samples from two villages (Almuatan and Alsabkha) out of 107 (1.87\%) female mosquitoes from Haroob Governorate were found positive for the sporozoites of Plasmodium falciparum. Similarly, 3 out of 150 (2\%) female mosquito samples from Um-alkhameir, AL-Khobah Governorate, were also found positive. Around fourfold increase of the sporozoite rate (from 0.61 to 2.0\%) in An. arabiensis in Al-Khobah Governorate has been observed compared to the previous study of 2007-2008.

The wide spread of An. arabiensis in Jazan region with $>90 \%$ of the malaria cases caused by P. falciparum, along with infectivity rate ranges between 1.87 to $2.0 \%$ for P. falciparum in Al-Khobah and Haroob Governorates, suggests that $P$. falciparum is the most predominant malaria parasite and $A n$. Arabiensis is a very efficient malaria vector in the region. It also suggests more in-depth researches on the ecology, behavior, and control of An. Arabiensis to promote area-specific control programs.

Keywords: Malaria, Jazan, Saudi Arabia, Plasmodium falciparum, PCR, Anopheles arabiensis.

\section{Introduction}

Malaria is an infectious disease caused by the bites of female Anopheles mosquitoes infected with Plasmodium spp. (Cowman and Crabb, 2006). There are approximately fifteen Anopheles species present in Saudi Arabia, but only four play a major role in parasitic transmission; these species are Anopheles arabiensis, Anopheles sergentii, Anopheles stephensi, and Anopheles Superpictus (Zahar, 1985; Sebai, 1988). Anopheles arabiensis has been identified as the primary vector transmitting malaria in Tihama area (southwest of Saudi Arabia and northeast Yemen) (Alsheikh, 2011), and considered to be a very efficient transmitting vector in the Afro-tropical area, with large variations in life behaviour including feeding, resting, and breeding (Coetzee and Le Sueur, 1988; Beiern and Koros, 1991). Five species of Plasmodium have long been recognized to infect humans; these species include Plasmodium falciparum (the most vir-

ulent form of malaria with approximately 90\% malaria deaths globally), Plasmodium vivax (the commonest cause of malaria globally), Plasmodium malariae, Plasmodium ovale and Plasmodium knowlesi (WHO, 2016).

The annual estimation for malaria from December 2015 was 214 million cases and 438000 deaths, with 3.2 billion people were at risk of malaria transmission (WHO, 2016). The disease remains a considerable threat due to several reasons, such as transmission enabling environments, poverty, lack of awareness, impaired health system infrastructures, political and socioeconomic problems, mass population migration and the emergence of multi-drug resistance (WHO, 2011; WHO, 2014).

In Saudi Arabia, about 5\% of the Saudi population was at risk of malaria (approximately 2.4 million people) (Alsheikh, 2011). The disease was restricted to the South Western region of Tihama (Jazan and Asir),
\end{abstract}


where more than $70 \%$ of all malaria cases in the country are occurred (El Hassan et al, 2015). Moreover, from 2000 to 2014 there were 5522 known locally acquired cases of malaria and around 9936 imported cases (El Hassan et al, 2015).

Identifying of sporozoites of human malaria in the salivary glands of potential Anopheline vectors is the final step in establishing vector status (Alsheikh, 2011). Besides, the determination of sporozoite rates was considered as the most important entomological factor in the epidemiology of human malaria (Wirtz et al, 1987).

The intensity of malaria transmission is determined by calculating the entomological inoculation rate (EIR), as a simple estimated parameter, which is the product of the manbiting rate (defined as the number of bites per person per night) and the sporozoite rate (Reisen and Boreham, 1982; Dye, 1986). Although vectorial capacity was also a useful estimator of potential transmission intensity (Garret-Jones and Shidrawi, 1969), but. it is often difficult to determine with reliability owing to the numerous biological parameters required for its estimation.

There are three techniques have been used for identification of Plasmodium sporozoites in salivary glands of Anopheles female mosquitoes. These include; ordinary microscopy dissection, immunological techniques, and polymerase chain reaction (PCR) (Burkot et al, 1984; Beier et al, 1988; Alsheikh, 2011). The latter has the potential for detecting and screening malaria parasites, especially in endemic regions, as well as in monitoring the effectiveness of malaria therapy (Moody, 2002; Morassin et al, 2002; Gama et al, 2007).

Al-Maktari and Bassiouny (1999) in Yemen recorded sporozoites rate of $0.7 \%(4 / 600)$ for $P$. falciparum in An. arabiensis using microscopy method.

In Jazan region, Al-Sheikh (2011) reported $0.61 \%$ as sporozoite rate of $P$. falciparum in An. arabiensis collected in 2007 2008 using nested-PCR. To the best of the authors knowledge, since that date no other data in Jazan region or other areas of Saudi Arabia has been published on the determination of sporozoite rate of $P$. falciparum in An. arabiensis using nested-PCR. The present study is thus conducted to detect and identify the infectious Plasmodium species inside the malaria vector Anopheles arabiensis in Jazan region using nested-PCR techniques comparing to the previous data.

\section{Materials and Methods}

Study site: This study was carried out at two small Governates (Al-Khobah, and Haroob) in the Jazan Region in Southwest Saudi Arabia, lies between $16^{\circ}-12$, and $18^{\circ}-25$, latitude north (Alsheikh, 2011), with a total area of about $22,000 \mathrm{~km} 2$ and 1.3 million populations (census 2011). Thirty percent of the population concentrated in six major cities, and the remainders living in over 3500 villages (Fig. 1).

Jazan region is situated in the subtropical zone and has average monthly temperatures ranging between $25.8^{\circ} \mathrm{C}$ in January to $33.4^{\circ} \mathrm{C}$ in July. The average relative humidity ranges from $55 \%$ and $72.5 \%$. The rainy season is started at August through October with a monthly average of 77 and $56.7 \mathrm{~mm}$, respectively (Alsheikh, 2011).

Mosquito samples collection: An. arabiensis specimens were collected from indoor human dwellings of 26 villages distributed in tow Governorates (Al-Khobah and Haroob) from January to December 2015 (Tab. 1). The two Governorates were selected based on the presence of An. Arabiensis and the reports of malaria cases. The collection of specimens was performed using Pyrethrum Knockdown (PKD) collections as described by WHO (1992). Collected mosquitoes were brought to the National Center for Vector-Borne Diseases in Jazan for morphological and molecular identification, and sporozoite rate determination.

Mosquito examination: Mosquitoes were identified based on diagnositic morphological features (Mattingly and Knight, 1956; Taai et al, 2017). A total of 257 An. arabiensis females were preserved individually in $1.5 \mathrm{ml}$ plastic tube, labeled, capped, and stored at -86 until further investigated. After 
removing legs, wings, and abdomen, the mosquito samples were homogenized individually in a mortar and pestle (mini borosilicate glass chamber length $60 \mathrm{~mm} /$ pestle di- ameter $9.0 \mathrm{~mm}$ 3.0Ml, Fisherbrand) in $100 \mu \mathrm{L}$ of Minimum Essential Media (MEM) (manufactured Euro Clone, UK). Homogenate was saved in -86 degree till next procedure

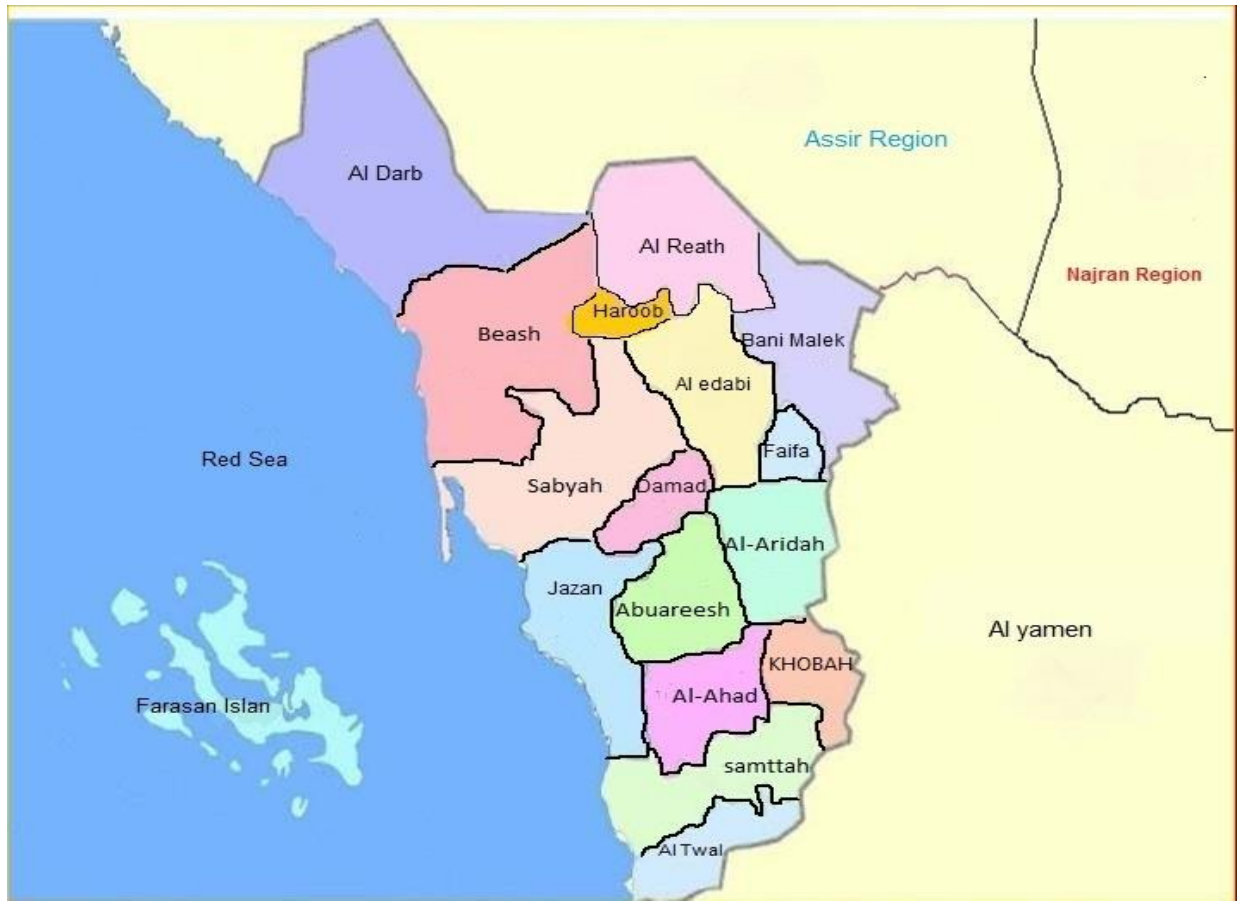

Fig 1: Map of Jazan region showing its different Governorates

DNA extraction: DNA was extracted from the stored homogenate using RealLine DNA - Extraction 2 (BIORON Diagnostic, Germany) following the manufacture's recommendations: $300 \mu \mathrm{L}$ of lysis Reagent with sorbent (magnetic particles) added to homogenate in 1.5 tubes and placed into the thermo shaker for five minutes at $65^{\circ} \mathrm{C}$, $1300 \mathrm{rpm}$. Then $400 \mu \mathrm{L}$ of DNA precipitation solution was added to each tube and mixed for 15 seconds in a vortex. Samples were then centrifuged at $13000 \mathrm{rpm}$ for five minutes at room temperature then the supernatant discarded and the pellet was washed twice and dried for 2-3 minutes at room temperature. Specimen solution used to resuspend the DNA. The extracted DNA stored at $-86^{\circ} \mathrm{C}$ till next procedure

Molecular detection; a- Mosquito identification: Morphological identification of $A n$. arabiensis was confirmed by PCR using the procedure described by Scott et al (1993), and the primer used and PCR conditions. $b$ Plasmodium detection: Nested PCR proce- dures were carried out for detection and identification of Plasmodium species as described by Snounou et al. (1993a). DNA samples were amplified by oligonucleotide primers obtained from Integrated DNA Technology (Belgium), targeting the Plasmodium small subunit ribosomal RNA (ssRNA) genes (Waters and McCutchan, 1989). Primer pair's rPLU5 \& rPLU6 used to detect Plasmodium in Primary amplification and species-specific primers rFAL1/rFAL2 ( $P$. falciparum) and rVIV1/ rVIV2 ( $P$. vivax) for nested PCR in 2 separated reactions (Tab. 2).

Primary and nested PCR were carried out in total $25 \mu 1$ reaction volume, each containing $12.5 \mu \mathrm{l}$ GoTag®G2 green master mix ready to use from Promega and $25 \mu \mathrm{M}$ of each primer. Five $\mu l$ of extracted DNA was used as a sample for primary amplification and $2 \mu 1$ of PCR product for the nested PCR. In each run, neg- ative $\&$ positive controls were included. Ther-mal cycling was done in T100 thermal cycler (Bio-Rad, USA). 
PCR primers and conditions. PCR products of nested amplification were analyzed by gel electrophoresis (1.5 agarose in Tris-Acetate EDTA buffer) staining with ethidium promide. Visualization was done using Gel Doc XR Imaging System (Bio-Rad).

\section{Results}

A total of $315 \mathrm{bp}$ segments of IGS region of rRNA gene sequences of An. Arabiensis were amplified (Fig. 2). An. arabiensis was found as the predominant Anopheles mosquitoes in all the collection sites. All sam- ples which were previously identified morphologically as An. arabiensis had been also molecularly confirmed by PCR (Fig 2). The molecular surveillance covered a total of 26 villages distributed in tow Governates (16 in Al-Khobah and 10 in Horoob) and lasted from January to December 2015. Two samples from two villages (Almuatan and Alsabkha) of one hundred and seven (1.87\%) female mosquitoes collected from Haroob Governorate were positive for sporozoites of P. falciparum (Tab. 3).

Table 1: Anopheles arabiensis collected from 26 villages of Al-khobah and Haroob (January to December 2015)

\begin{tabular}{|c|c|c|c|c|c|}
\hline \multirow{2}{*}{ Serial No. } & \multicolumn{2}{|c|}{ Al-khobah Governorate } & \multirow{2}{*}{ Serial No. } & \multicolumn{2}{|c|}{ Haroob Governorate } \\
\hline & Villages & No. of samples & & Villages & No. of samples \\
\hline 1 & Wabrah & 5 & 1 & Gaeim Mahroog & 13 \\
\hline 2 & Gaeim Mzubaid & 15 & 2 & Haroob city & 4 \\
\hline 3 & Zahr Aljamal & 5 & 3 & Al-muatan & 12 \\
\hline 4 & Um-alturab & 17 & 4 & Al-gahmah & 9 \\
\hline 5 & Al-mujarad & 19 & 5 & Al-sabkhah & 21 \\
\hline 6 & Al-mushbah & 6 & 6 & Al-maseer & 9 \\
\hline 7 & Al-mudeirah & 6 & 7 & Al-zamlah & 11 \\
\hline 8 & Al-mafrag & 5 & 8 & Al-dahmah & 11 \\
\hline 9 & Al-abteiah & 11 & 9 & Al-zahab & 9 \\
\hline 10 & Um-alkhameir & 22 & 10 & Al-kudmy & 8 \\
\hline 11 & Al-garn & 5 & & & \\
\hline 12 & Al-girwaneiah & 6 & & & \\
\hline 13 & Um-alhegil & 7 & & & \\
\hline 14 & Al-rahmaneiah & 7 & & & \\
\hline 15 & Al-jarshab & 8 & & & \\
\hline 16 & Shargan & 6 & & & \\
\hline & Total & 150 & Total & & 107 \\
\hline
\end{tabular}

Table 2: Primers used in detection of Plasmodium's sporozoite and identification of An. arabiensis, and PCR

\begin{tabular}{|c|c|c|c|c|}
\hline Species & $\begin{array}{l}\text { Primer } \\
\text { Name }\end{array}$ & Sequence (5-3) & $\begin{array}{l}\text { PCR Product } \\
\text { size (BP) }\end{array}$ & PCR Condition (Initial denaturation) \\
\hline $\begin{array}{l}\text { Plasmodium } \\
\text { sp. }\end{array}$ & $\begin{array}{l}\text { rPLU5 } \\
\text { rPLU6 }\end{array}$ & $\begin{array}{l}\text { CCTGTTGTTGCCTTAAACTTC } \\
\text { TTAAAATTGTTGCAGTTAAAACG }\end{array}$ & 1100 & $\begin{array}{l}\text { at } 94^{\circ} \mathrm{C} \text { for } 3 \text { min, } 35 \text { cycles of denaturation at } \\
94^{\circ} \mathrm{C} \text { for } 60 \text { seconds, annealing at } 60^{\circ} \mathrm{C} \text { for } 90 \\
\text { seconds, extension at } 72^{\circ} \mathrm{C} \text { for } 90 \text { seconds } \\
\text { then extension for } 5 \text { minutes }\end{array}$ \\
\hline $\begin{array}{l}P . \\
\text { falciparum }\end{array}$ & $\begin{array}{l}\text { rFAL1 } \\
\text { rFAL2 }\end{array}$ & $\begin{array}{l}\text { TTAAACTGGTTTGGGAAAACC } \\
\text { AAATATATT } \\
\text { ACACAATGAACTCAATCATGA } \\
\text { CTACCCGTC }\end{array}$ & 205 & $\begin{array}{l}\text { at } 94^{\circ} \mathrm{C} \text { for } 3 \text { min, } 35 \text { cycles of denaturation at } \\
94^{\circ} \mathrm{C} \text { for } 60 \text { seconds, annealing at } 55^{\circ} \mathrm{C} \text { for } 90 \\
\text { seconds, extension at } 72^{\circ} \mathrm{C} \text { for } 90 \text { seconds } \\
\text { then extension for } 5 \text { minutes }\end{array}$ \\
\hline P. vivax & $\begin{array}{l}\text { rVIV1 } \\
\text { rVIV2 }\end{array}$ & $\begin{array}{l}\text { CGCTTCTAGCTTAATCCACAT } \\
\text { AACTGATAC } \\
\text { ACTTCCAAGCCGAAGCAAAGA } \\
\text { AAGTCCTTA } \\
\end{array}$ & 120 & $\begin{array}{l}\text { at } 94^{\circ} \mathrm{C} \text { for } 3 \text { min, } 35 \text { cycles of denaturation at } \\
94^{\circ} \mathrm{C} \text { for } 60 \text { seconds, annealing at } 55^{\circ} \mathrm{C} \text { for } 90 \\
\text { seconds, extension at } 72^{\circ} \mathrm{C} \text { for } 90 \text { seconds } \\
\text { then extension for } 5 \text { minutes }\end{array}$ \\
\hline $\begin{array}{l}\text { An. } \\
\text { arabiensis }\end{array}$ & $\begin{array}{l}\text { Universal } \\
\text { primer } \\
\text { Species } \\
\text { specific }\end{array}$ & $\begin{array}{l}\text { GTG TGC CCC TTC CTC GAT GT } \\
\text { AAG TGT CCT TCT CCA TCC TA }\end{array}$ & 315 & $\begin{array}{l}\text { at } 94^{\circ} \mathrm{C} \text { for } 3 \text { min, } 35 \text { cycles of denaturation at } \\
94^{\circ} \mathrm{C} \text { for } 60 \text { seconds, annealing at } 50^{\circ} \mathrm{C} \text { for } 60 \\
\text { seconds, extension at } 72^{\circ} \mathrm{C} \text { for } 60 \text { seconds } \\
\text { then extension for } 5 \text { minutes }\end{array}$ \\
\hline
\end{tabular}

Table 3: Detection of Plasmodium sporozoites from An. arabiensis by PCR method

\begin{tabular}{|l|c|c|c|c|}
\hline Governorate & No of villages surveyed & Total samples & Positive \% & Species detected \\
\hline Horoob & 10 & 107 & $2(1.87 \%)$ & $P$. falciparum \\
\hline Al-Khobah & 16 & 150 & $3(2 \%)$ & P. falciparum \\
\hline Total & 26 & 257 & $5(2.3)$ & $P$. falciparum \\
\hline
\end{tabular}

Three out of one hundred fifty (2\%) female mosquito samples collected from 16 villages of $\mathrm{Al}$-Khobah Governorate were positive, mainly from Um-Alkhameir village. All positive nested PCR samples of $P$. falciparum showed band in (205bp) (Fig 3). 


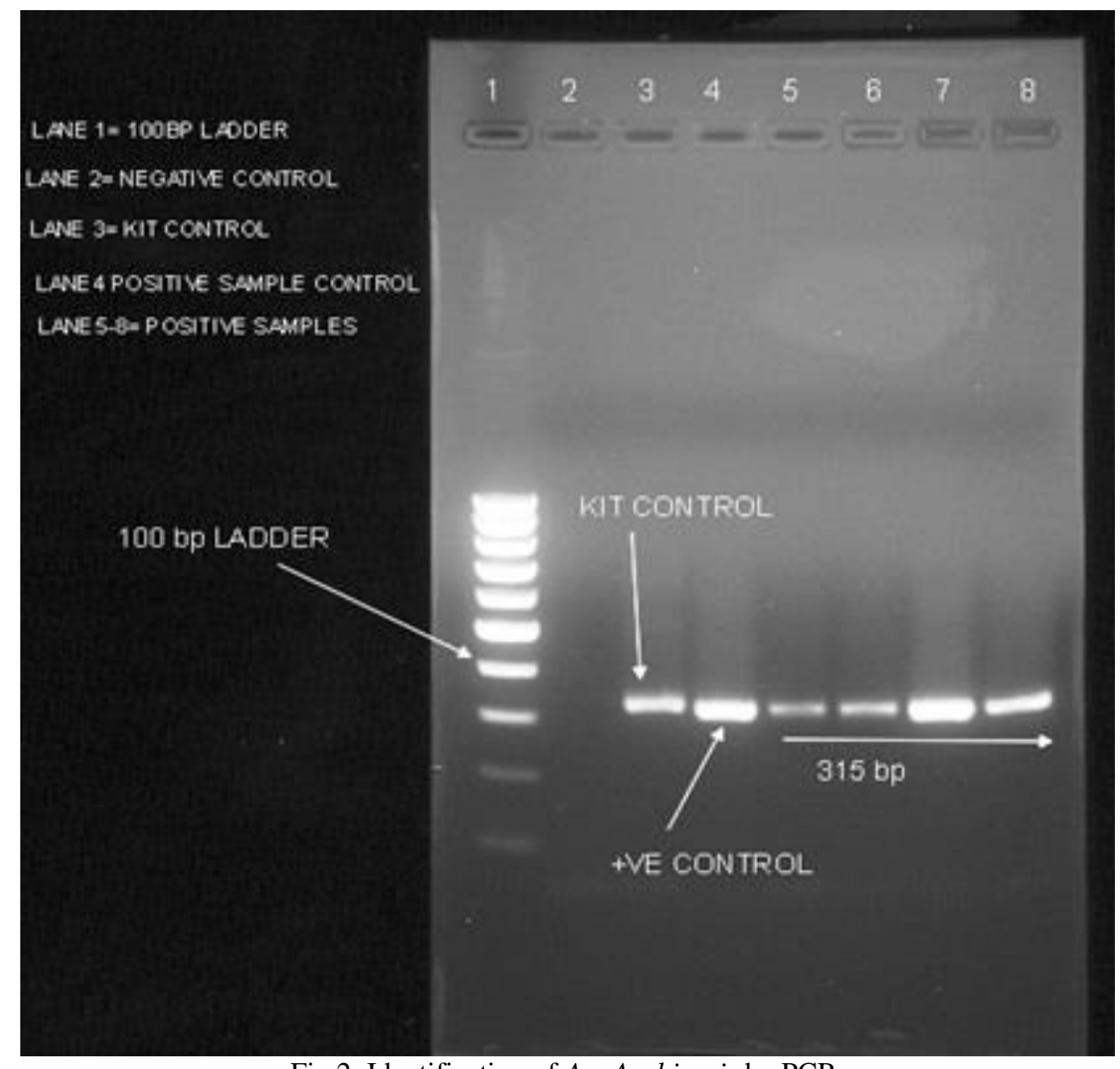

Fig 2: Identification of An. Arabiensis by PCR.

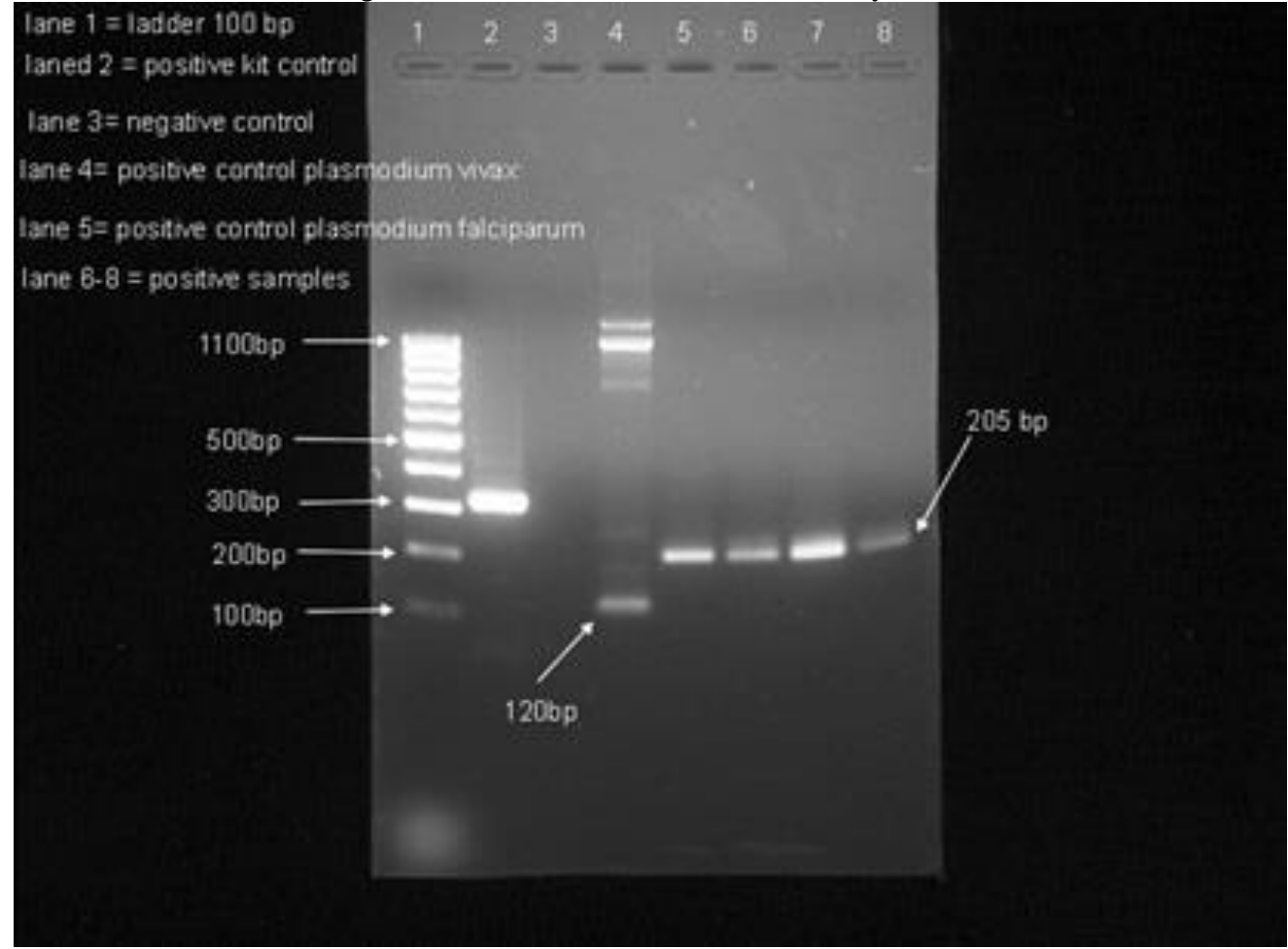

Fig 3: Detection of Plasmodium species by PCR method in An. arabiensis. 


\section{Discussion}

Anopheles arabiensis is the potential primary vector of the malaria in Jazan region. Alsheikh (2011) identified An. arabiensis in the Tihama Region (Saudi Arabia and Yemen) using speciesspecific diagnostic PCR, and showed that it is the only member of An. gambiae complex found in the Tihama Region.

In the present study, only detected the Plasmodium species in female of An. arabiensis using nested-PCR method was $P$. falciparum, a result which agreed with Alsheikh (2011) who reported that $P$. falciparum represents more than $95 \%$ of malaria cases in the Tihama Region (including Jazan Region). The determination of sporozoites infection in wild Anopheles mosquitoes considers an integral part in vector incrimination and malaria transmission dynamics in affected areas and epidemiological study (Alsheikh, 2011).

In this study, sporozoite rate of $1.87 \%$ \& $2 \%$ in Haroob and Alkhobah Governorates, respectively, reinforces the need to intensify the control efforts to compact the vector and reduce malaria transmission.

It was noticed a fourfold increase in sporozoite rate of $P$. falciparum in An. arabiensis in Alkhobah Governorate in the present study from 0.61 to $2 \%$ compared to the previous study in 20072008 (Alsheikh, 2011). This could be attributed may be to the ongoing war on the border of Yemen, where Alkhobah is located, which hinders the proper control measures against An. arabiensis usually used to be conducted in the area.

Harada et al. (2000) reported fourfold increase in the sporozoite rate $(0.62$ to $2.2 \%$ ) in Anopheles gambiae S.S. in Ghana using PCR method. In Solomon's Islands, $P$. falciparum was detected in $15.2 \%$ of An. farauti by PCR technique (Wilson et al, 1998).

Few previous studies in the Tihama Region had determined the sporozoite rate of Plasmodium species in Anopheles mosquitoes. For instance in Saudi Arabia, Plasmodium sporozoites had been detected in $0.65 \%$ of An. arabiensis using nested- PCR (Alsheikh, 2011), and in $0.9 \%$ of 2921 An. arabiensis (23 P. falciparum, and $2 P$. vivax) using ELISA method, while P. falciparum sporozoites were detected in An. sergentii (2/295) and a single female of An. algerien-sis in Yemen (Al-Eryani et al., 2016).

In East African countries such as $\mathrm{Su}-$ dan, the $P$. falciparum sporozoite rate in An. arabiensis was found to be $4.5 \%$ in Sennar State using ELISA technique (Elmahdi et al, 2012), and 1.4-15\% in eastern part of the country (Hamad et al, 2002), in Ethiopia, it was $0.3 \%$ for $P$. falciparum and $0.5 \%$ for $P$. vivax (Tirados et al, 2006), and in Eritrea ranged from 0.54 to $1.3 \%$ (Shililu et al, 2004).

In Asia, the sporozoite rate of $P$. falciparum was higher (10\%) in An. stephensi from District Shiekhupura in Pakistan (Oneeb et al, 2015). Whereas, in various parts of India, sporozoite rates ranged from 0.012 to $0.2 \%$ in An. annularis were reported using microscopic method, but the malaria parasite species could not be identified (Dash et al, 1982; Gunasekaran et al, 1989; Ghosh et al, 1985). But, Mahapatra et al. (2006) in Keonjhar district, Orissa, India, have detected 3.4\% sporozoite rate in Anopheles annularis using PCR technique, and have identified the malaria parasite species to be $P$. falciparum.

Infectivity rate of $10.6 \%$ P. falciparum in An. gambiae complex was reported by Snounou et al. (1993b) in Guinea Bissau using nested-PCR method. Four out of five ( $80 \%$ sporozoite rate) wild caught Anopheles dirus were found positive for the sporozoites of $P$. falciparum using PCR method, although they were negative when using ELISA technique (Tassanakajon et al, 1993), which reflected the high sensitivity of the PCR 
method. Variations in sporozoite rates in An. arabiensis from a country to another or within the same country could be attributed to the seasonal variations in transmission (Alsheikh, 2011).

The wide spread of An. arabiensis in Jazan region with $>90 \%$ of the malaria cases caused by $P$. falciparum, along with infectivity rate ranges between 1.87 to $2.0 \%$ for $P$. falciparum, suggests more in-depth researches on its ecology, behavior, and control to promote areaspecific control programs.

\section{Conclusion}

The current study indicated the significance of using PCR technology in detecting Plasmodium species in Anopheles mosquitoes. The outcome results revealed an infectivity rate of Anopheles arabiensis ranged between 1.87 to $2.0 \%$ for P. falciparum in two Governorates; Haroob and Al-Khobah of the Jazan Region, respectively.

The wide spread of An. arabiensis in the Jazan Region with $>90 \%$ of the malaria cases caused by $P$. falciparum, along with infectivity rate ranges between 1.87 to $2.0 \%$ for P. falciparum in Al-Khobah and Haroob Governorates, suggested that $P$. falciparum is the most predominant malaria parasite and $A n$. arabiensis is a very efficient malaria vector in the region.

Further detection for the sporozoite of Plasmodium species in Anopheles mosquitoes need to be conducted in the rest of the Governorates of the Jazan region to determine their infectivity rates by malaria parasites. The importance of detailed knowledge of disease vectors along with their sporozoite rates is of vital importance in the promotion of area-specific control interventions and programs.

Compete of interest: The authors declared no compete of interest.

\section{References}

Al-Eryani, SM, Kelly-Hope, L, Harbach, RE, Briscoe, AG, Barnish, G, et al, 2016: Entomological aspects and the role of hu- man behaviour in malaria transmission in a highland region of the Republic of Yemen. Malar. J. 15:1-9.

Al-Maktari, M, Bassiouny, H, 1999: Bionomics of Anopholine vectors in Zabid District, Al-Hodeidah, Governorate, Republic of Yemen, East. Mediterr. Health J. 5(4): 698-705.

Al-Sheik, AA, 2011: Larval habitat, ecology, seasonal abundance and vectorial role in malaria transmission of Anopheles arabiensis in Jazan Region of Saudi Arabia. J. Egypt. Soc. Parasitol. 41, 3:615-34.

Beier, J, Asiago C, Onyango, K, Koros, J, 1988: ELISA absorbance cut-off method affected malaria sporozoite rate determination in wild Afro-tropical Anopheles. Med. Vet. Entomol. 2:

259-64.

Beier, J, Koros, J, 1991: Visual assessment of sporozoite and blood meal ELISA samples in malaria field studies. J. Med. Entomol. 28:805-8.

Burkot, T, Zavala, F, Gwadz, R, Collins, F, Nurssenweig, R, et al, 1984: Identification of malaria-infected mosquitoes by a two-site enzyme-linked immunosorbant assay. Amer. J. Trop. Med. Hyg. 33, 2:227-31.

Coetzee, M, Le Sueur, D, 1988: Effects of salinity on the larvae of some Afro-tropical anopheline mosquitoes. Med. Vet. Entomol. 2, 4:385-90.

Cowman, AF, Crabb, BS, 2006: Invasion of red blood cells by malaria parasites. Cell. 124, 4:755-66.

Dash, AP, Bendle, MS, Das, AK, Das, M, Dwivedi, SR, 1982: Role of Anopheles annularis as a vector of malaria in the inland of Orissa. J. Com. Dis. 14, 3:224-9.

Dye, C, 1986: Vectorial Capacity: Must we me-asure all its components? Parasitol. Today 2, 8: 203-9.

ElHassan, IM, Sahly, A, Alzahrani, MH, Al-hakeem, RF, Alhelal, M, et al, 2015: Progress toward malaria elimination in Jazan Province, Kingdom of Saudi Arabia: 2000-2014. Malar. J. 14, 1:1-10.

Elmahdi, ZA, Nugud, AA, Elhassan, I.IM, 2012: Estimation of malaria transmission intensity in Sennar state, central Sudan. EMRO Bull. 18, 9:951-6.

Gama, BE, do ES Silva-Pires, F, Lopes, MNK R, Cardoso, MAB, Britto, C, et al, 2007: Real-time PCR versus conventional PCR for malaria parasite detection in low- 
grade parasitemia. Exp. Parasitol. 116, 4: 427-32.

Garret-Jones, C, Shidrawi, G, 1969: Malaria vectorial capacity of a population of Anopheles gambiae: an exercise in epidemiological entomology. Bull. WHO 40, 4:53145.

Ghosh, KK, Chakarborty, S, Bhattacharya, S, Palit, A, Neelam, T, et al, 1985: Anopheles annularis as a vector of malaria in rural West Bengal. Indian J. Malariol. 22: 65-70.

Gunasekaran, K, Sahu, SS, Parida, SK, Sada-nandane, C, Jambulingam, P, et al,. 1989: Ano-pheline fauna of Koraput district, Orissa State, with particular reference to transmission of malaria. Indian J. Med. Res. 89:340-3.

Hamad, AA, Nugud, H, Arnot, DE, et al, 2002: A marked seasonality of malaria transmission in two rural sites in eastern Sudan. Acta Trop. 83:71-82.

Harada, M, Ishikawa, H, Matsuoka, H, Ishii, A, Suguri, S, 2000: Estimation of the sporozoite rate of malaria vector using the PCR and a mathematical model. Acta Med. Okayama 54, 4:165-71.

Mahapatra, N, Marai, NS, Ranjit, MR, Parida, SK, Hansdah, DP, et al, 2006: Detection of Plasmodium falciparum infection in Anopheles mosquitoes from Keonjhar district, Orissa, India. J. Vect. Bor. Dis. 43: 191-4.

Mattingly, PF, Knight, KL, 1956: The mosquito of Arabia. Bull. Brit. Mus. Nat. Hist. (Ent.). 4, 3:89-141.

Moody, A, 2002: Rapid diagnostic tests for malaria parasites. Clin. Microbial. Rev. 15: 66-78.
Morassin, B, Fabre, R, Berry, A, Magnaval, J F, 2002: One year's experience with the polymerase chain reaction as a routine method for the diagnosis of imported malaria. Am. J. Trop. Med. Hyg. 66:503-8.

Oneeb, M, Maqbool, A, Lateef, M, Babar, ME, 2015: Detection of Plasmodium falciparum infection in Anopheles stephensi in Punjab, Pakistan. Pakis. J. Zool. 47, 4: 1192-5.

Reisen, W, Boreham, P, 1982: Estimates of malaria vectorial capacity for Anopheles culicifacious and Anopheles stephensi in rural Punjab province Pakistan. J. Med. Entomol. 19, 1:98-103.

Scott, JA, Brogdon, WG, Collins, FH, 1993: Id-entification of single specimens of the Anopheles gambiae complex by the PCR. Am. J. Trop. Med. Hyg. 49:520-9.

Sebai, Z. 1988: Malaria in Saudi Arabia. Trop. Doctor 18:183-8.

Shililu, J, Ghebremeskel, T, Seulu, F, et al, 2004: Seasonal abundance, vector behavior, and malaria parasite transmission in Eritrea. J. Am. Mosq. Cont. Assoc. 20:15564.

Snounou, GS, Viriyakosol, S, Zhu, XP, Jarra, W, Pinheiro, L, et al, 1993a: Brown. high sensitivity of detection of human malaria parasites by the use of nested OCR. Mol. Biochem. Parasitol. 61, 2:31520.

Snounou, GS, Pinheiro, L, Goncalves, A, Fonseca, L, Dias, F, et al, 1993b: The importance of sensitive detection of malaria parasites in the human and insect hosts in epidemiological studies, as shown by the analysis of field sample from Guinea Bissau. Trans. R. Soc. Trop. Med. H 